\title{
The Effect of Delivery Mode on Thiol-Disulfide Balance in the Umbilical Cord Blood
}

\author{
Doğum Şeklinin Umbilikal Kord Kanındaki Tiyol/Disülfit Dengesine Etkisi
}

Selda SONGUR DAĞLII $\operatorname{Recai~DAĞLI} I^{2}$

\section{$\underline{0 ̈ Z}$}

Amaç: Günümüzde, oksidatif stress seviyesi sıklıkla tiyol/disülfit dengesini inceleyen metodlar yoluyla saptanır. Elektif sezaryen (ES) ve vajinal doğumlardaki (VD) oksidatif stresi tiyol/disülfit dengesini inceleyerek karşılaştırmayı amaçladık.

Araçlar ve Yöntem: Çalışmaya 48 VD ve 57 ES dahil edildi. Çalışmada, standardizasyon amacıyla, spinal anestezi ile yapılan ES'lar incelendi. Plasenta ayrıldıktan hemen sonra umblikal arterden beş mililitre kan örneği alındı. Serum nativ tiyol, total tiyol, disülfit analiz edildi. Disülfit/native tiyol (\%), Disülfit/total tiyol (\%), and nativ tiyol/total tiyol (\%) oranları hesaplandı.

Bulgular: ES grubundaki nativ tiyol, total tiyol, disülfit, and disülfit/total tiyol oranları VD grubundan belirgin olarak düşüktü $(446.27 \pm 48.01,484.26 \pm 47.50, \mathrm{p}<0.001,493.28 \pm 69.14,541.43 \pm 64.21, \mathrm{p}<0.001,23.75 \pm 9.27,28.58 \pm 11.11, \mathrm{p}=0.017$ ve $4.68 \pm 1.48$, $5.80 \pm 2.04, \mathrm{p}=0.002$, sirasıyla). Gruplar arasında disülfit/nativ tiyol ve nativ tiyol/total tiyol oranları bakımından farklılık yoktu (p>0.05). Gruplar arasında yaş ortalaması, doğum haftası ve doğum ağırlığı açısından fark yoktu ( $>0.05)$. ES grubundaki yenidoğanların ilk ve 5. dakika Apgar skorları VD grubundan daha yüksekti $(\mathrm{p}<0.01)$.

Sonuç: Tiyol/disülfit dengesi doğum yönteminden etkilenmektedir. Vajinal doğumdaki oxidatif stres seviyesi elektif sezaryendekinden daha yüksektir.

Anahtar Kelimeler: sezaryen; disülfit; oksidatif stres; tiyol; vajinal doğum.

\section{ABSTRACT}

Purpose: Today, the Oxidative stress level is frequently determined through the methods examining the thiol-disulfide balance. We aimed to compare oxidative stress in elective caesarean sections (ECS) and vaginal deliveries (VD) by examining the thiol-disulfide balance.

Materials and Methods: Forty- eight VDs and 57 ECSs were included in the study. For standardization, pregnant women who underwent spinal anesthesia for ECS were examined in the study. Five milliliters of blood samples were taken from the umbilical artery immediately after placenta delivery. Serum native thiol, total thiol, disulfide was analyzed in blood samples. Disulfide/native thiol (\%), disulfide/total thiol (\%), and native thiol/total thiol (\%) ratios were calculated.

Results: Native thiol, total thiol, disulfide, and disulfide/total thiol ratios were significantly lower in the ECS group than in the VD group $(446.27 \pm 48.01$ vs $484.26 \pm 47.50, \mathrm{p}<0.001,493.28 \pm 69.14$ vs $541.43 \pm 64.21, \mathrm{p}<0.001,23.75 \pm 9.27$ vs. $28.58 \pm 11.11, \mathrm{p}=0.017$, and $4.68 \pm 1.48$ vs $5.80 \pm 2.04, p=0.002$, respectively). There were no differences between the groups in terms of disulfide/native thiol, and native thiol/total thiol ratios ( $p>0.05$ ). There were no differences between the groups in terms of mean age, gestational week, and birth weight ( $p>0.05$ ). First and 5th Apgar scores of the newborn of the ECS group were higher than the VD group $(p<0.01)$

Conclusion: The thiol-disulfide balance is affected by delivery mode. The oxidative stress level in vaginal deliveries is higher than in elective caesarean sections.

Key Words: caesarean section; disulfides; oxidative stress; thiols; vaginal delivery

Received: 16.12.2020; Accepted: 19.01.2021

${ }^{1}$ Asst. Prof.Dr., Department of Obstetrics and Gynecology, Kirsehir Ahi Evran University Faculty of Medicine, Kirsehir, Turkey.

${ }^{2}$ Assoc. Prof.Dr., Department of Anaesthesiology and Reanimation, Kirsehir Ahi Evran University Faculty of Medicine, Kirsehir, Turkey.

Corresponding author: Selda SONGUR DAĞLI, Department of Obstetrics and Gynecology, Kirsehir Ahi Evran University Faculty of Medicine, Kirsehir

Turkey. e-posta: seldasongurdagli@ hotmail.com 


\section{INTRODUCTION}

A substance that donates electrons is oxidized, and a substance that gains electrons is reduced. Reduction reactions occur via electron transfer and via a change in orbits of electrons in covalent bonds. Oxidized agents are electrophilic and gain electrons from other molecules, and as a result, they produce free radicals. ${ }^{1}$ These free radicals are very labile and active, and may be of endogenous or exogenous origin. Thiol-disulfides (TD) are also radicals that are formed in this oxidation process. TD is the sulfide-added form of thiol. The organism tries to preserve the native thiol and TD balance by working together with oxidative and antioxidative systems. Native thiol is oxidized and transforms into the disulfide form and, through the process of the antioxidant mechanism, the sulfide bond is separated and converted back into a thiol. ${ }^{2}$ Organisms try to fight these free radicals and prevent cell damage caused by free radicals. Oxidative stress (OS) is a condition that occurs when an organism fails to defend against free radicals. It is thought that the OS plays a role in the etiopathogenesis of many diseases, especially cancer. ${ }^{3}$ OS can be tested for practically using the method of Erel et al., which enables the measurement of these metabolites. ${ }^{2}$

Pregnancy is a physiologic process in which oxidant and antioxidant systems work to maintain a balance, and as the trimesters increase, OS increases, women in whom OS increases, pregnancy complications such as hyperemesis gravidarum and preeclampsia may be more severe. In cases of complications, OS may rise and enter a vicious circle. ${ }^{4-7}$ When the literature is examined, it is observed that different marker levels were examined in complicated pregnancies or according to the urgency of the delivery. ${ }^{8-13}$ However, there are few standardized studies investigating the relationship between delivery mode, TD balance, and OS levels. Accordingly, we planned this research to support the literature.

In this study, we aimed to compare the TD balance in elective caesarean sections (ECS) and vaginal deliveries (VD) using a practical method that has not been sufficiently studied.

\section{MATERIAL and METHODS}

Study Design

This study is a prospective observational study.

Study Site

Pregnant women followed up in the Obstetrics and Gynecology Clinic of Kirsehir Ahi Evran University Training and Research Hospital between August $1^{\text {st }}$, 2017, and July $1^{\text {st }}, 2018$, and who underwent VD or ECS were included in the study.

Inclusion and exclusion criteria

The gestational week was calculated according to the last menstrual date and ultrasonographic examination in the first trimester. Healthy pregnant women in the $37^{\text {th }}-41^{\text {st }}$ gestational week who did not use drugs except iron and folic acid supplementation and who underwent VD or ECS were included in the study.

In this study, only, uncomplicated vaginal term deliveries have were examined in the VD group: Pregnant women with the head presentation, unassisted and no complications VD, who did not require medication, oxygen and intravenous fluid infusion from the beginning of labor to termination were included in the study.

In ECS group, pregnant women whose labor process did not start spontaneously and was performed an elective caesarean section, such as having prior uterine surgery, primiparous with breech presentation, and the secondary elective caesarean section were included in the study. Women who had preeclampsia, gestational diabetes mellitus, placenta previa, placental detachment, and chronic diseases such as hypertension, diabetes mellitus, and connective tissue disease were not included. Besides, pregnant women who had multiple pregnancies, complications during labor such as fever, meconiumstained amniotic fluid, chorioamnionitis, and intrauterine exitus were not included in the study. Pregnant women who needed medication such as oxytocin for induction of labor, were excluded from the study. 
Procedure:

Two groups were determined: the VD group and the ECS group.

VD procedures: After the active phase of the labor action started, the necessary monitorisation of the pregnant women was performed. Labors terminating within 8 hours, without needing an episiotomy, and required no medication, intravenous fluids and oxygen therapy during the course were included in the study.

ECS procedures: Standard hemodynamic monitorisation was performed with electrocardiography (ECG), peripheral oxygen saturation $\left(\mathrm{SpO}_{2}\right)$, and noninvasive blood pressure (NIBP) monitoring before the ECS. An intravenous route was obtained, and $500 \mathrm{~mL} 0.9 \% \mathrm{NaCl}$ infusion was started.

The type of anesthesia was determined by a joint decision of the pregnant-obstetrician-anesthesiologist triplicate following the American Society of Anesthesiologists Physical Status (ASA). The selected anesthesia technique was performed using standard procedures by an anesthesiologist who was not in the research group and was responsible for obstetric surgery. For standardization, pregnant women who underwent spinal anesthesia for ECS were included in the study.

Standard spinal anesthesia procedure: A 26-G spinal needle (Atrocan ${ }^{\circledR}$, Brown, Germany) was inserted at the L3-L4 or L4-L5 vertebral level with the women in the sitting position, and $10 \mathrm{mg}$ heavy bupivacaine was administered. After checking the settlement of sensory block at the T6 level with a pinprick test, the surgical procedure was permitted. Oxygen $(2 \mathrm{~L} / \mathrm{min})$ was administered using a nasal mask until the fetus was delivered.

In both methods, the umbilical cord was clamped, and then the placenta was delivered after the baby was delivered. The placenta was removed from the surgical site to obtain blood samples.
Data collection procedure

Five-milliliter blood samples were taken from the umbilical artery just after the fetus and placenta were delivered following VD and ECS. The samples were first centrifuged at $3000 \mathrm{rpm}$ and stored at $-80^{\circ} \mathrm{C}$ until required for analysis. Serum native thiol $(\mu \mathrm{mol} / \mathrm{L})$, total thiol $(\mu \mathrm{mol} / \mathrm{L})$, and disulfide $(\mu \mathrm{mol} / \mathrm{L})$ were measured using the method described by Erel and Neselioglu. ${ }^{2}$ Disulfide/native thiol (\%), disulfide/total thiol $(\%)$, and native thiol/total thiol (\%) ratios were calculated.

Birth weight (gr), first and $5^{\text {th }}$ minute Apgar scores of the newborn, maternal age (years), gestational age (week) were recorded.

Ethical Approval and Informed Consent

The Clinical Trials Ethics Committee of the Kirsehir Ahi Evran University approved this study (Date: 03/07/2017, Decision no: 2017-13/138). This observational study was planned following the current Declaration of Helsinki.

Pregnant women who met the inclusion criteria were informed about the research, and an informed consent was obtained from each participant.

Data Analysis and Management

The primary outcomes of this study are between-group comparisons of native thiol and total thiol levels, and disulfide/native thiol (\%), disulfide/total thiol (\%), and native thiol/total thiol $(\%)$ ratios.

Secondary outcomes are maternal age (years), gestational age (week), birth weight (gr), first and 5th minute Apgar scores of the newborn.

Statistical Analyses

Statistical analyses were performed using SPSS 17.0 version (SPSS Inc., Chicago, IL). The normal distribution of continuous variables was checked using the Kolmogorov-Smirnov and Shapiro-Wilk tests. The Independent $\mathrm{t}$-Test and the Mann-Whitney $\mathrm{U}$ test were used to compare continuous variables in normally and 
non-normally distributed data, respectively. Descriptive statistics are expressed as $\mathrm{n}(\%)$, mean $\pm \mathrm{SD}$, median (Q1$\mathrm{Q} 3)$, and 95\% Confidence Interval (95\%CI).

\section{RESULTS}

There were a total of 1024 VDs and 1132 ECSs in our clinic in the study period. During the ethics committee approval period, a total of 105 women who met the inclusion criteria, ECSs $(n=57,54.3 \%)$ and VDs $(n=48$, $45.7 \%$ ) could be included.

There were no differences between the groups in terms of mean age, gestational week, and birth weight $(\mathrm{p}>0.05)$. First Apgar (8.37 (95\% CI, 8.20 to 8.54) vs. 8.02 (95\% CI, 7.98 to 8.06), $\mathrm{p}<0.01)$ and 5th Apgar scores of the newborn (9.51 (95\% CI, 9.35 to 9.67$)$ vs $9.02(95 \% \mathrm{CI}$, 8.98 to 9.06 ), $\mathrm{p}<0.01$ ) of the ECS group were higher than the VD group. The basic data are shown in Table 1.

Table 1. Baseline data.

\begin{tabular}{|c|c|c|c|}
\hline & $\begin{array}{l}\text { ECS } \\
(n=57)\end{array}$ & $\begin{array}{l}\text { VD } \\
(n=48)\end{array}$ & $\begin{array}{l}\mathrm{P} \\
\text { Value }\end{array}$ \\
\hline & $(54.3 \%)$ & $(45.7 \%)$ & \\
\hline \multirow{2}{*}{$\begin{array}{l}\text { Maternal age } \\
\text { (years) }\end{array}$} & $27.75 \pm 4.82$ & $28.69 \pm 5.73$ & \multirow[t]{2}{*}{$0.367^{\mathrm{a}}$} \\
\hline & $\begin{array}{l}28.00(23.50 \text { to } \\
32.00)\end{array}$ & $\begin{array}{l}29.00(24.25 \text { to } \\
32.00)\end{array}$ & \\
\hline \multirow{2}{*}{$\begin{array}{l}\text { Birth weight } \\
\text { (gr) }\end{array}$} & $3372.98 \pm 350.35$ & $3268.75 \pm 469.64$ & \multirow{2}{*}{$0.196^{\mathrm{a}}$} \\
\hline & $\begin{array}{l}3400.00(3150.00 \text { to } \\
3560.00)\end{array}$ & $\begin{array}{l}3255.00(3000.00 \text { to } \\
3585.00)\end{array}$ & \\
\hline \multirow{2}{*}{$\begin{array}{l}\text { Gestational age } \\
\text { (week) }\end{array}$} & $38.98 \pm 0.48$ & $38.52 \pm 2.13$ & \multirow{2}{*}{$0.148^{\mathrm{b}}$} \\
\hline & $\begin{array}{l}39.00(39.00 \text { to } \\
39.00)\end{array}$ & $\begin{array}{l}39.00(38.00 \text { to } \\
40.00)\end{array}$ & \\
\hline \multirow{2}{*}{$\begin{array}{l}\text { Apgar } \\
\text { (1. Minute) }\end{array}$} & $8.37 \pm 0.64$ & $8.02 \pm 0.14$ & \multirow[t]{2}{*}{$<0.01^{\mathrm{b}}$} \\
\hline & 8.00 (8.00 to 9.00$)$ & $8.00(8.00$ to 8.00$)$ & \\
\hline \multirow{2}{*}{$\begin{array}{l}\text { Apgar } \\
\text { (5. Minute) }\end{array}$} & $9.51 \pm 0.60$ & $9.02 \pm 0.14$ & \multirow{2}{*}{$<0.01^{\mathrm{b}}$} \\
\hline & $\begin{array}{l}10.00(9.00 \text { to } \\
10.00)\end{array}$ & $9.00(9.00$ to 9.00$)$ & \\
\hline
\end{tabular}

ECS: elective caesarean sections, VD: vaginal deliveries,

All variables are expressed as $\mathrm{n}(\%)$, mean $\pm \mathrm{SD}$, and median (Q1-Q3).

${ }^{\mathrm{a}}$ Independent t-Test, ${ }^{\mathrm{b}}$ Mann-Whitney U Test.

Native thiol, total thiol, disulfide, and disulfide/total thiol ratios were significantly lower in the ECS group than in the VD group (446.27 \pm 48.01 vs $484.26 \pm 47.50$, $\mathrm{p}<0.001$, $493.28 \pm 69.14$ vs $541.43 \pm 64.21, \mathrm{p}<0.001,23.75 \pm 9.27$ vs $28.58 \pm 11.11, \mathrm{p}=0.017$, and $4.68 \pm 1.48$ vs $5.80 \pm 2.04, \mathrm{p}=$ 0.002, respectively) (Figure1-2).

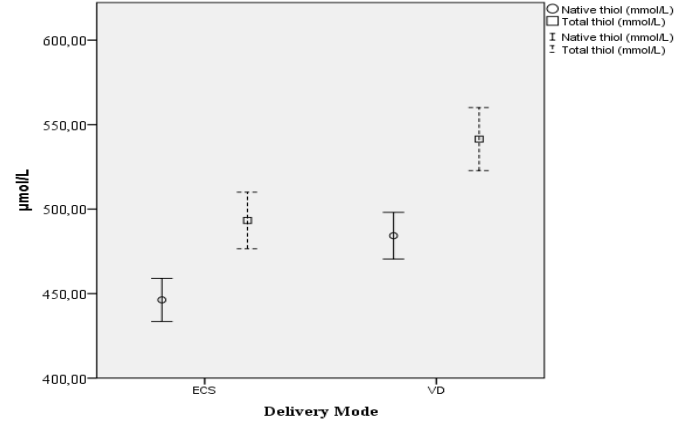

Figure 1. A comparison of native thiol and total thiol according to delivery mode (ECS: elective caesarean sections, VD: vaginal deliveries, mean $\pm 95 \% \mathrm{CI}$ )

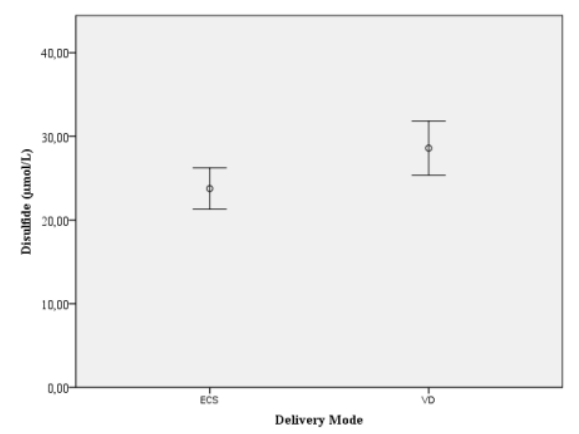

Figure 2. A comparison of disulfide according to delivery mode (ECS: elective caesarean sections, VD: vaginal deliveries, mean $\pm 95 \% \mathrm{CI}$ )

There were no differences between the groups in terms of disulfide/native thiol and native thiol/total thiol ratios ( $p>0.05)$. A comparison of TD values is shown in Table 2.

Table 2. The values of thiol-disulfide hemostasis in the cord blood.

\begin{tabular}{|c|c|c|c|}
\hline & $\begin{array}{c}\text { ECS } \\
(\mathrm{n}=57) \\
(54.3 \%)\end{array}$ & $\begin{array}{c}\text { VD } \\
(n=48) \\
(45.7 \%)\end{array}$ & $P$ value \\
\hline $\begin{array}{l}\text { Native thiol } \\
(\mu \mathrm{mol} / \mathrm{L})\end{array}$ & $\begin{array}{l}446.27 \pm 48.01 \\
457.60(411.15 \text { to } \\
487.10)\end{array}$ & $\begin{array}{l}484.26 \pm 47.50 \\
489.75(453.55 \text { to } \\
516.70)\end{array}$ & $<0.001^{\mathrm{a}}$ \\
\hline $\begin{array}{l}\text { Total thiol } \\
(\mu \mathrm{mol} / \mathrm{L})\end{array}$ & $\begin{array}{l}493.28 \pm 69.14 \\
502.00 \text { ( } 449.50 \text { to } \\
545.50)\end{array}$ & $\begin{array}{l}541.43 \pm 64.21 \\
555.50(499.00 \text { to } \\
578.50)\end{array}$ & $<0.001^{\mathrm{a}}$ \\
\hline $\begin{array}{l}\text { Disülfide } \\
(\mu \mathrm{mol} / \mathrm{L})\end{array}$ & $\begin{array}{l}23.75 \pm 9.27 \\
24.75(17.92 \text { to } \\
33.16)\end{array}$ & $\begin{array}{l}28.58 \pm 11.11 \\
29.70(21.11 \text { to } \\
36.43)\end{array}$ & $0.017^{\mathrm{a}}$ \\
\hline $\begin{array}{l}\text { Disülfide/Native } \\
\text { thiol (\%) }\end{array}$ & $\begin{array}{l}5.22 \pm 1.78 \\
5.38(4.08 \text { to } 6.47)\end{array}$ & $\begin{array}{l}5.14 \pm 1.74 \\
5.42(4.28 \text { to } 6.32)\end{array}$ & $0.809^{\mathrm{a}}$ \\
\hline $\begin{array}{l}\text { Disülfide/Total } \\
\text { thiol (\%) }\end{array}$ & $\begin{array}{l}4.68 \pm 1.48 \\
4.85(3.77 \text { to } 5.73)\end{array}$ & $\begin{array}{l}5.80 \pm 2.04 \\
6.07(4.67 \text { to } 7.24)\end{array}$ & $0.002^{\mathrm{a}}$ \\
\hline $\begin{array}{l}\text { Native } \\
\text { thiol/Total } \\
\text { thiol (\%) }\end{array}$ & $\begin{array}{l}90.75 \pm 3.12 \\
90.29(88.54 \text { to } \\
92.49)\end{array}$ & $\begin{array}{l}89.71 \pm 3.48 \\
89.16(87.34 \text { to } \\
91.44)\end{array}$ & $0.059^{\mathrm{b}}$ \\
\hline
\end{tabular}

ECS: elective caesarean sections, VD: vaginal deliveries, All variables are expressed as $\mathrm{n}(\%)$, mean $\pm \mathrm{SD}$, and median (Q1Q3).

${ }^{\mathrm{a}}$ Independent t-Test, ${ }^{\mathrm{b}}$ Mann-Whitney U Test. 


\section{DISCUSSION}

We found that OS was significantly higher in the VD group than in the ECS group. Disulfide levels, which reflect OS, were higher in the VD group than in the ECS group. Besides, native thiol levels, which reflect antioxidation, were also higher in the VD group than in the ECS group. In addition, we found that Apgar scores were statistically higher in the ECS group, but this was not clinically significant.

Işı et al. showed that native and total thiol levels were higher in the VD group, but unlike our study, they found no difference between the groups in terms of the disulfide/total thiol ratio. ${ }^{14}$ In that study, there was no information regarding whether a standard anesthesia protocol was performed or not. It is known that the type of anesthesia, the drugs used, and the amount of oxygen administered can affect OS. ${ }^{15}, 16$ We included women who underwent only standard spinal anesthesia during ECS to eliminate factors that affect OS levels.

Cindrova-Davies et al. performed a pathologic and chemical study on placentas to assess OS levels after VD and ECS. They found that OS level was higher in the VD group than in the ECS group, as we found in our study. ${ }^{17}$ Tai-Ho Hung et al. performed a study on both maternal and placental tissues to determine if the form of labor affected OS levels. The authors found that the OS level was higher in the VD group than in the ECS group. However, there was also no standardization for the type of anesthesia and labor in their study. ${ }^{13}$ Vakilian et al. performed a similar study to ours, but used thiobarbituric reactive substances (TABRS), total antioxidant power (TAP), and total thiol molecules (TTM) as markers. They found that the OS level was higher in the VD group than in the ECS group in accordance with our findings. Once again, there was no standardization for VD and ECS in that study. ${ }^{9}$

Parmigiani et al. evaluated OS by looking at the value of reactive oxygen metabolites (ROMs) in umbilical cord blood, and concluded that newborns' antioxidant mechanisms affected OS, and that OS was not affected by delivery mode. ${ }^{18}$ In that study, ROMs, which represent OS and occur in the last step, were examined. In our study, both oxidation and antioxidant markers were studied separately. The disulfide ratio, which represents OS, and the native thiol ratio, which represents antioxidation, were higher in the VD group than in the ECS group.

The OS level may be affected by changes in steroid hormone and melatonin levels during the day. ${ }^{19}$ In our study, ECSs were performed during daytime and VDs in all hours of the day. The difference in OS level between groups may be due to this reason. In our study, thiol balance was measured only in cord blood sample. The simultaneous measurement of thiol balance in the maternal serum samples could be valuable in order to validate the results. Therefore, future studies involving the VDs and ECSs that will take place in the same period were planned. As a result, the thiol-disulfide balance was affected by the delivery mode. The oxidative stress level in the vaginal deliveries was higher than in the elective caesarean sections.

\section{Conflict of Interest}

The authors declare no conflict of interest.

\section{Acknowledgements}

We would like to thank the team of biochemistry laboratory for the assistance in this research.

\section{REFERENCES}

1. Arasimowicz M, Floryszak-Wieczorek J, Milczarek G, Jelonek T. Nitric oxide, induced by wounding, mediates redox regulation in pelargonium leaves. Plant Biol (Stuttg) 2009;11(5):650-663.

2. Erel O, Neselioglu S. A novel and automated assay for thiol/disulphide homeostasis. Clin Biochem. 2014;47(18):326-332.

3. Burton GJ, Jauniaux E. Oxidative stress. Best Pract Res Clin Obstet Gynaecol. 2011;25(3): 287-299.

4. Kundi H, Erel O, Balun A, et al. Association of thiol/disulfide ratio with syntax score in patients with NSTEMI. Scand Cardiovasc J. 2015;49(2):95-100.

5. Ergin M, Cendek BD, Neselioglu S, Avsar AF, Erel O. Dynamic thiol-disulfide homeostasis in hyperemesis gravidarum. J Perinatol. 2015;35(10):788-792.

6. Korkmaz V, Kurdoglu Z, Alisik M, et al. Impairment of thiol-disulfide homeostasis in preeclampsia. J Matern Fetal Neonatal Med. 2016;29(23):3848-3853.

7. Onat T, Kırmızı DA, Başer E, et al. The relationship between oxidative stress and preeclampsia. The serum ischemia-modified albumin levels and thiol/disulfide homeostasis. Turk J Obstet Gynecol. 2020;17(2):102-107.

8. Lurie S, Matas Z, Boaz M, Fux A, Golan A, Sadan O. Different degrees of fetal oxidative stress in elective and 
emergent cesarean section. Neonatology. 2007;92(2):111115.

9. Vakilian K, Ranjbar A, Zarganjfard A, et al. On the relation of oxidative stress in delivery mode in pregnant women; a toxicological concern. Toxicol Mech Methods. 2009;19(2):94-99.

10. Wang M, Liang Q, Li H, et al. Normal pregnancy-induced amino acid metabolic stress in a longitudinal cohort of pregnant women: novel insights generated from UPLCQTOFMS-based urine metabolomic study. Metabolomics. 2016;12(8):131.

11. Kacerovsky M, Tothova L, Menon R, et al. Amniotic fluid markers of oxidative stress in pregnancies complicated by preterm prelabor rupture of membranes. J Matern Fetal Neonatal Med. 2015;28(11):1250-1259.

12. Aksoy AN, Gözükara I, Kucur SKl, Batmaz G, Laloğlu E, Bulut E. Spontan vajinal doğum yapan hastalarda maternal serum beyin kaynaklı nörotrofik faktör ve malondialdehit düzeylerindeki değişimlerin araştırılması. Zeynep Kamil Tıp Bül. 2015;46(1):6-12.

13. Hung TH, Chen SF, Lo LM, Li MJ, Yeh YL. The associations between labor and delivery mode and maternal and placental oxidative stress. Reprod Toxicol 2011;31(2):144-150.

14. Ulubas Isik D, Akdas Reis Y, Bas AY, et al. The effect of the modes of delivery on the maternal and neonatal dynamic thiol-disulfide homeostasis. J Matern Fetal Neonatal Med. 2019;32(23):3993-3997.

15. Yalcin S, Aydogan H, Kucuk A, et al. Supplemental oxygen in elective cesarean section under spinal anesthesia: Handle the sword with care. Braz J Anesthesiol. 2013;63(5):393397.

16. Kulacoglu H, Ozdogan M, Gurer A, et al. Prospective comparison of local, spinal, and general types of anaesthesia regarding oxidative stress following Lichtenstein hernia repair. Bratisl Lek Listy. 2007;108(8):335-339.

17. Cindrova-Davies T, Yung HW, Johns J, et al. Oxidative stress, gene expression, and protein changes induced in the human placenta during labor. Am J Pathol. 2007;171(4):1168-1179.

18. Parmigiani S, Payer C, Massari A, Bussolati G, Bevilacqua G. Normal values of reactive oxygen metabolites on the cord-blood of full-term infants with a colorimetric method. Acta Biomed Ateneo Parmense. 2000;71(1-2):59-64.

19. Chiba T, Omori A, Takahashi K, et al. Correlations between the detection of stress-associated hormone/oxidative stress markers in umbilical cord blood and the physical condition of the mother and neonate. J Obstet Gynaecol Res. 2010;36(5):958-964 